\title{
PATENT EUROPEJSKI O JEDNOLITYM SKUTKU - KONSTRUKCJA PRAWNA I TREŚĆ
}

\section{WPROWADZENIE}

Ochrona patentowa w państwach członkowskich Unii Europejskiej może być obecnie uzyskana na podstawie patentów krajowych albo europejskich. Patenty krajowe są udzielane na rzecz podmiotów z całego świata przez urzędy poszczególnych państw na podstawie ustaw krajowych (w Polsce - przez Urząd Patentowy RP na podstawie ustawy prawo własności przemysłowej ${ }^{1}$ ).

Drugi sposób uzyskania ochrony umożliwia Konwencja o udzielaniu patentów europejskich $(\mathrm{KPE})^{2}$, na podstawie której patenty są udzielane przez Europejski Urząd Patentowy w Monachium (EUP). Również o patenty europejskie moga się ubiegać podmioty z całego świata, jednakże ochrona uzyskana $\mathrm{w}$ tym trybie obowiązuje tylko na terytorium jednego, kilku albo wszystkich państw stron $\mathrm{KPE}^{3}$, w zależności od wyboru dokonanego przez podmiot ubiegający się o ochronę.

Patent europejski nie jest jednolitym tytułem ochronnym, lecz stanowi wiązkę patentów krajowych podlegających ustawodawstwom tych państw stron KPE, w których uzyskał on skutki prawne ${ }^{4}$. Powstanie owych skutków jest w poszczególnych państwach uzależnione od tzw. walidacji, której na wniosek uprawnionego dokonuja organy krajowe po otrzymaniu tłumaczenia opisu patentowego na język urzędowy danego państwa ${ }^{5}$. Wymóg ten, mający oparcie w art. $65 \mathrm{KPE}$, jest uzasadniony faktem, że patenty europejskie sa przez EUP udzielane tylko w jednym języku (angielskim, francuskim albo niemieckim), $\mathrm{w}$ związku z czym podmioty funkcjonujące w państwach, których językiem urzędowym jest inny język (np. polski), nie miałyby możliwości zapoznania się

${ }^{1}$ Ustawa z 30 czerwca 2000 r., Dz. U. 2003, Nr 119, poz. 1117 ze zm. (dalej jako: p.w.p.).

${ }^{2}$ Konwencja, sporządzona 5 października $1973 \mathrm{r}$. w Monachium, weszła w życie w stosunku do Polski 1 marca 2004 r. Ówcześnie obowiązujący tekst KPE został ogłoszony, wraz z regulaminem wykonawczym i protokołami stanowiącymi jej integralną część, w: Dz. U. 2004, Nr 79, poz. 737. Akt rewidujący z 29 listopada 2000 r., który wszedł w życie 13 grudnia 2007 r., został ogłoszony w Dz. U. 2007, Nr 236, poz. 1736.

${ }^{3}$ Do KPE należy 38 państw (28 państw członkowskich UE i 10 innych państw, np. Islandia, Norwegia, Szwajcaria).

${ }^{4}$ Jak stanowi art. 2 ust. 2 KPE, patent europejski posiada w każdym umawiającym się państwie, dla którego został udzielony, ten sam skutek i podlega tym samym warunkom, co patent krajowy udzielony przez to państwo, chyba że konwencja stanowi inaczej. Zob. też art. $64 \mathrm{KPE}$.

${ }^{5} \mathrm{Z}$ zastrzeżeniem odrębności wynikajacych z porozumienia londyńskiego w sprawie stosowania art. 65 KPE (Dz. Urz. EUP 2001, nr 12, s. 550). Polska nie jest stroną tej umowy międzynarodowej. 
z sytuacją patentową obowiązująca $w$ tych państwach ${ }^{6}$. Kwestie językowe maja istotne znaczenie ze względu na konieczność ustalenia zakresu wyłączności wynikającej z patentów, co jest warunkiem bezpieczeństwa prawnego działalności, zwłaszcza gospodarczej, prowadzonej przez inne podmioty. Mając to na względzie, KPE zawiera regulacje chroniące interesy podmiotów z państw posiadających język urzędowy inny niż ten, w którym patent europejski został udzielony? ${ }^{7}$.

Trzecim sposobem uzyskania ochrony patentowej mają być patenty europejskie o jednolitym skutku (określane dalej również jako ,,jednolite patenty"). Mają one obowiązywać w państwach członkowskich Unii Europejskiej uczestniczących we wzmocnionej współpracy w dziedzinie tworzenia jednolitej ochrony patentowej ${ }^{8}$. Wzmocniona współpraca w tej dziedzinie została ustanowiona:

1) rozporządzeniem Parlamentu Europejskiego i Rady (UE) nr 1257/2012 z 17 grudnia 2012 r. wprowadzającym wzmocnioną współpracę w dziedzinie tworzenia jednolitego systemu ochrony patentowej ${ }^{9}$,

2) rozporządzeniem Rady (UE) nr 1260/2012 z 17 grudnia 2012 r. wprowadzającym wzmocnioną współpracę $\mathrm{w}$ dziedzinie tworzenia jednolitego systemu ochrony patentowej w odniesieniu do mających zastosowanie ustaleń dotyczacych tłumaczeń ${ }^{10}$.

Procedurę wzmocnionej współpracy rozpoczęto w grudniu 2010 r., po niepowodzeniu kolejnej próby utworzenia patentu Unii Europejskiej ${ }^{11}$. Polska była w pierwszej grupie 12 państw, które złożyły wniosek o ustanowienie wzmocnionej współpracy; ostatecznie uczestniczy w niej 25 państw członkowskich. Inicjatywie tej sprzeciwiły się Hiszpania i Włochy, które następnie zaskarżyły decyzję Rady z 10 marca 2011 r. upoważniającą do podjęcia wzmocnionej współpracy do unijnego Trybunału Sprawiedliwości (TS ${ }^{12}$. Wyrokiem z 16 kwietnia 2013 r. skargi obu państw zostały oddalone ${ }^{13}$, co oznacza, że TS nie podzielił argumentów podważających legalność wspomnianej decyzji. Zarzuty Włoch i Hiszpanii dotyczyły dopuszczalności wzmocnionej współpracy (np. w kontekście kompetencji, o których mowa w art. 20 TUE) ${ }^{14}$, natomiast

\footnotetext{
${ }^{6}$ Tłumaczenia patentów europejskich są publikowane przez Urząd Patentowy RP, co zapewnia ich powszechną dostępność w języku polskim.

7 Zob. np. art. 70 ust. 3 KPE, a także art. 7 ust. 2 ustawy z 14 marca 2003 r. o dokonywaniu europejskich zgłoszeń patentowych oraz skutkach patentu europejskiego w Rzeczypospolitej Polskiej (Dz. U. Nr 65, poz. 598 ze zm.). Zob. szerzej A. Nowicka, Patenty europejskie $i$ ich skutki w Polsce, w: System prawa prywatnego, t. 14A: Prawo wtasności przemystowej, red. R. Skubisz, Warszawa 2012, s. 143 i n.

${ }^{8}$ Wzmocniona współpraca jest szczególną procedurą tworzenia unijnych aktów prawnych. Zob. art. 20 Traktatu o Unii Europejskiej (TUE) i art. 326-334 Traktatu o funkcjonowaniu Unii Europejskiej (TfUE).

9 Dz. Urz. UE L 361 z 31 grudnia 2012 r., s. 1-8 (dalej jako: rozporządzenie nr 1257/12).

${ }^{10}$ Dz. Urz. UE L 361 z 31 grudnia 2012 r., s. 89-92 (dalej jako: rozporządzenie nr 1260/12).

${ }^{11} \mathrm{Na}$ temat blisko 40-letniej historii prac związanych $\mathrm{z}$ tworzeniem unijnego patentu zob. A. Nowicka, Patent europejski a próby ustanowienia patentu Unii Europejskiej, „Ruch Prawniczy, Ekonomiczny i Socjologiczny" 2010, z. 4, s. 39 i n.

12 Zob. skargi w sprawach C-274/11 (Dz. Urz. UE C 219 z 23 lipca 2011 r., s. 12) oraz C-295/11 (Dz. Urz. UE C 232 z 6 sierpnia 2011 r., s. 21).

${ }^{13}$ Zob. wyrok TS w sprawach C-274/11 i C-295/11 (Dz. Urz. UE C 164 z 8 czerwca 2013 r., s. 3).

${ }^{14}$ Według art. 20 TUE wzmocniona współpraca może być ustanowiona tylko w ramach kompetencji niewyłącznych Unii Europejskiej. Do tego rodzaju kompetencji TS zakwalifikował, wbrew zarzutom
} 
przedmiotem orzeczenia TS nie były przepisy tworzące jednolitą ochronę patentową i jej system językowy. Trybunał będzie jednak miał okazję zająć stanowisko w tych sprawach, gdyż 22 marca 2013 r. Hiszpania wniosła do TS nowe skargi (C-146/13 i C-147/13) ${ }^{15}$, tym razem o stwierdzenie nieważności rozporządzeń nr 1257/12 i nr 1260/12.

Jednolita ochrona patentowa, tworzona na podstawie obu rozporządzeń, jest powiązana z utworzeniem Jednolitego Sądu Patentowego (JSP). Sąd ten ma powstać na podstawie umowy międzynarodowej (porozumienie JSP) ${ }^{16}$, która ma być zawarta między państwami członkowskimi Unii Europejskiej, bez udziału samej Unii (a także bez udziału państw stron KPE nienależących do Unii). Będzie on posiadał wyłączna jurysdykcję nie tylko w sprawach dotyczących patentów europejskich o jednolitym skutku, lecz także „klasycznych” patentów europejskich, a nadto - dodatkowych świadectw ochronnych (SPC) ${ }^{17}$. Wyłączna jurysdykcją JSP będą objęte m.in. sprawy o naruszenie wymienionych praw i ich unieważnienie. Wbrew sugestii mogącej wynikać $z$ nazwy omawianej umowy, nie tylko tworzy ona nowy sąd patentowy (JSP) i określa jego strukturę, lecz także reguluje wiele innych zagadnień, np. treść praw wyłącznych wynikających z obu rodzajów patentów (patentu europejskiego i patentu europejskiego o jednolitym skutku), ograniczenia tych praw oraz środki ochrony obu rodzajów patentów (i SPC), zarówno proceduralne, jak i materialne. Jak wspomniano, w odniesieniu do patentów europejskich (i SPC) zagadnienia te obecnie podlegają ustawom państw stron KPE i jurysdykcji organów krajowych. Jeśli Polska zwiąże się porozumieniem JSP, to spowoduje to nie tylko wyłączenie jurysdykcji tych organów, lecz także będzie oznaczać, że wymienione sprawy przestaną podlegać prawu krajowemu, a będą podlegać nowej umowie międzynarodowej.

Rozporządzenia nr 1257/12 i nr 1260/12 weszły w życie 20 stycznia 2013 r., lecz maja być stosowane od 1 stycznia 2014 r. albo od dnia wejścia w życie porozumienia JSP, w zależności od tego, która data będzie późniejsza.

Porozumienie JSP zostało otwarte do podpisu 19 lutego $2013 \mathrm{r}$. i tego dnia zostało podpisane przez 24 państwa członkowskie ${ }^{18}$, a 5 marca $2013 \mathrm{r}$. - przez Bułgarię. Podpisu nie złożyły Hiszpania i Polska. Dotychczas ratyfikacji dokonała Austria (7 sierpnia 2013 r.).

Według art. 89 ust. 1 porozumienia JSP wejdzie ono w życie 1 stycznia 2014 r. albo pierwszego dnia czwartego miesiąca po złożeniu trzynastego dokumentu ratyfikacji, albo pierwszego dnia czwartego miesiąca po wejściu

\footnotetext{
Hiszpanii i Włoch, kompetencję określoną w art. 118 TfUE, dotycząca tworzenia „,europejskich praw własności intelektualnej”.

${ }^{15}$ Zarzuty dotyczące obu rozporządzeń, sformułowane w skargach C-146/13 i C-147/13: Dz. Urz. UE C 171 z 15 czerwca 2013 r., s. 15-16.

${ }^{16}$ Tekst porozumienia JSP (Agreement on a Unified Patent Court) jest dostępny w dziale „Informacje”, Dz. Urz. UE C 175 z 20 czerwca 2013 r., s. 1-40.

17 Dodatkowe świadectwa ochronne (SPC) są udzielane na warunkach określonych w rozporządzeniu nr 469/2009 (Dz. Urz. UE L 152 z 16 czerwca 2009 r.) i w rozporządzeniu nr 1610/96 (Dz. Urz. WE L 198 z 8 sierpnia 1996 r.). W prawie polskim ochrona wynikająca z tych świadectw jest określana mianem dodatkowego prawa ochronnego (zob. art. $75^{1}-75^{10}$ p.w.p.).

${ }^{18}$ Informacje o pracach związanych z tworzeniem JSP zawarte są na: www.unified-patent-court.org.
} 
w życie zmian do rozporządzenia Rady (UE) $\mathrm{nr} 1215 / 2012^{19}$ określających stosunek tego rozporządzenia do porozumienia JSP, w zależności od tego, które wydarzenie nastąpi później. W grupie 13 państw, których związanie się porozumieniem JSP stanowi minimalny wymóg jego wejścia w życie, muszą się znajdować Francja, RFN i Wielka Brytania. Rozporządzenie nr 1215/2012 przyjęte zostało 12 grudnia $2012 \mathrm{r}$., lecz będzie stosowane dopiero od 10 stycznia 2015 r. Procedura uchwalenia jego zmian, o których mowa w omawianym przepisie, została wszczęta na wniosek Komisji Europejskiej z 26 lipca 2013 r. (KOM [2013] 554). Można więc założyć, że rozpoczęcie stosowania tzw. pakietu patentowego (rozporządzeń nr 1257/12 i nr 1260/12 oraz porozumienia JSP) nastąpi nie wcześniej niż w pierwszej połowie 2015 r., jeśli porozumienie JSP zostanie ratyfikowane przez wymaganą liczbę 13 państw (chyba że TS uzna za zasadne skargi Hiszpanii w sprawach C-146/13 i C-147/13, podważające ważność obu rozporządzeń).

Patenty europejskie, które będą udzielane począwszy od dnia rozpoczęcia stosowania ,pakietu patentowego”, będą mogły uzyskać jednolity skutek zapewniający automatyczną ochronę w państwach uczestniczących we wzmocnionej współpracy. Jednakże - jak stanowi art. 18 ust. 2 akapit drugi rozporządzenia nr 1257/12 - ,w drodze odstępstwa od art. 3 ust. 1 i 2 oraz art. 4 ust. 1 patent europejski, którego jednolity skutek został wpisany do rejestru jednolitej ochrony patentowej, ma jednolity skutek jedynie w tych uczestniczących państwach członkowskich, w których Jednolity Sąd Patentowy ma wyłączną jurysdykcję w odniesieniu do patentów europejskich o jednolitym skutku w dniu wpisania do rejestru". Z postanowienia tego wynika, że patenty europejskie, których jednolity skutek zostanie - na wniosek uprawnionego wpisany do rejestru jednolitej ochrony patentowej, będą miały taki skutek tylko w tych państwach uczestniczących we wzmocnionej współpracy, które w dniu wpisania jednolitego skutku do tego rejestru będą związane porozumieniem JSP. Tak więc w pierwszym dniu czwartego miesiąca po złożeniu trzynastego dokumentu ratyfikacji jednolity skutek powstanie w 13 państwach (jeżeli będa już w mocy zmiany rozporządzenia nr 1215/2012), a każda kolejna ratyfikacja powodować będzie zwiększenie liczby państw, w których patenty europejskie będą mogły wywierać jednolity skutek. Biorąc pod uwagę treść przytoczonego wyżej art. 18 ust. 2 akapit drugi rozporządzenia nr 1257/12, w którym jest mowa 0 ,odstępstwie od art. 3 ust. 1 i 2 oraz art. 4 ust. 1” tego rozporządzenia, należy -jak się wydaje - przyjąć, że jednolity skutek będzie powstawał, niejako retroaktywnie, także na terytoriach tych państw uczestniczących we wzmocnionej współpracy, które zwiążą się (ratyfikują) porozumienie JSP w dacie późniejszej niż data jego wejścia w życie.

\footnotetext{
${ }^{19}$ Rozporządzenie Parlamentu Europejskiego i Rady (UE) nr 1215/2012 z 12 grudnia 2012 r. w sprawie jurysdykcji i uznawania orzeczeń sądowych oraz ich wykonywania w sprawach cywilnych i handlowych (Dz. Urz. UE L 351, 20 grudnia 2012 r.). Jest to przekształcona wersja obecnie obowiązującego rozporządzenia nr 44/2001 (Dz. Urz. WE L 12 z 16 stycznia 2001 r.), które z dniem 10 stycznia 2015 r. zostanie zastąpione rozporządzeniem nr 1215/2012.
} 
Mimo wielu apeli przedsiębiorców i ekspertów ${ }^{20}$, a także m.in. sejmowej Komisji Innowacyjności i Nowoczesnych Technologii ${ }^{21}$, polski rząd nie wycofał się z decyzji o udziale we wzmocnionej współpracy. W świetle przytoczonego wyżej przepisu art. 18 ust. 2 akapit drugi rozporządzenia nr 1257/12 niepodpisanie przez Polskę porozumienia JSP (i niezwiązanie się nim droga ratyfikacji) może zapobiec obowiązywaniu w naszym kraju patentów europejskich o jednolitym skutku, a tym samym - wysoce niekorzystnym konsekwencjom zarówno jednolitej ochrony patentowej, jak i rozwiązań zawartych w porozumieniu $\mathrm{JSP}^{22}$. W takim bowiem razie patenty europejskie nie będa miały w Polsce jednolitego skutku, lecz - tak jak obecnie - będą musiały być walidowane i tłumaczone na nasz język, a ewentualne spory będą w Polsce rozpatrywane przez sady krajowe, a nie JSP. Natomiast, co wymaga podkreślenia, podmioty polskie będą mogły uzyskiwać jednolite patenty $\mathrm{w}$ tych państwach uczestniczących we wzmocnionej współpracy, w których patenty europejskie będą miały jednolity skutek.

Patenty europejskie o jednolitym skutku będą mogły uzyskać nie tylko podmioty z państw Unii Europejskiej, lecz także z całego świata. Możliwość ta ma dotyczyć patentów udzielanych przez EUP począwszy od daty rozpoczęcia stosowania obu rozporządzeń (określonej w art. 18 ust. 2 akapit pierwszy rozporządzenia $\mathrm{nr}$ 1257/12). W rachubę wchodzą więc także patenty europejskie udzielone na wynalazki, których zgłoszenia zostały dokonane kilka, a nawet kilkanaście lat wcześniej, w zależności od czasu trwania procedury przed EUP.

\section{PATENT EUROPEJSKI O JEDNOLITYM SKUTKU - KONSTRUKCJA PRAWNA}

Jednolitą ochronę ma zapewniać patent, który w rozporządzeniu nr 1257/12 został określony mianem ,,patent europejski o jednolitym skutku” (European patent with unitary effect). Będzie on udzielany przez EUP w dotychczasowym trybie i na zasadach uregulowanych w KPE (dotyczących również przesłanek zdolności patentowej), z tym jednak, że po udzieleniu nie będzie on wiązką patentów krajowych, lecz - na wniosek uprawnionego - uzyska jednolity

\footnotetext{
${ }^{20}$ Zob. np. list otwarty profesorów: S. Sołtysińskiego, A. Szajkowskiego, J. Szwaji, R. Markiewicza, A. Nowickiej i R. Skubisza, opubl. w maju 2012 r. w Internecie, np. na stronach Polskiej Izby Rzeczników Patentowych (www.rzecznikpatentowy.org.pl) oraz w dodatku do „Rzeczpospolitej” z 18 czerwca 2012 r., a także apele wystosowane m.in. przez Pracodawców Rzeczypospolitej Polskiej, Konfederację Pracodawców Prywatnych Lewiatan, Polski Związek Przemysłu Oświetleniowego, Polską Izbę Inżynierów Budownictwa, Polską Izbę Rzeczników Patentowych, Krajową Izbę Gospodarczą, Polski Związek Pracodawców Przemysłu Farmaceutycznego (zob. np. na: www.rzecznikpatentowy.org.pl; www.jednolitypatent.wordpress.com).

${ }^{21}$ Zob. dezyderat nr 5 do Prezesa Rady Ministrów z 6 grudnia 2012 r. oraz odpowiedź Ministra Gospodarki z 10 stycznia 2013 r. (www.sejm.gov.pl).

${ }^{22} \mathrm{Na}$ temat niekorzystnych konsekwencji ,pakietu patentowego” zob. stanowiska wymienione wyżej $\mathrm{w}$ przypisie 20, a także np. A. Nowicka, Kontrowersje dotyczace utworzenia jednolitej ochrony patentowej $i$ Jednolitego Sadu Patentowego. Analiza prawna (stan na 27 stycznia 2012 r.), „Rzecznik Patentowy” 2011 [2012], nr 2-4, s. 9 i n.
} 
skutek, o którym mowa w rozporządzeniu $\mathrm{nr}$ 1257/12, a jego reżim językowy będzie podlegał przepisom rozporządzenia nr 1260/12. Dla swojej skuteczności nie będzie wymagał walidacji, lecz będzie obowiązywał automatycznie. Uprawniony z patentu europejskiego o jednolitym skutku nie będzie miał obowiązku dostarczenia tłumaczenia na poszczególne języki urzędowe, lecz patent ten będzie obowiązywał $\mathrm{w}$ języku, w którym został udzielony (angielskim, francuskim albo niemieckim) ${ }^{23}$. W celu uniknięcia nieporozumień pojęciowych patent europejski, który - jeśli uprawniony nie wystąpi o jednolity skutek - nadal będzie mógł obowiązywać w wybranych przez niego państwach stronach KPE (i to również w państwach uczestniczących we wzmocnionej współpracy), jest w niniejszym opracowaniu określany jako „klasyczny” patent europejski.

Mimo że jednolity patent jest tworzony aktami prawa unijnego (rozporządzeniami $\mathrm{nr} 1257 / 12 \mathrm{i} \mathrm{nr} 1260 / 12$ ), wydanymi na podstawie art. 118 TfUE, nie będzie to patent Unii Europejskiej. Utworzenie takiego patentu wymagałoby zgody wszystkich państw członkowskich, a ponadto wiązałoby się z przystąpieniem Unii do KPE, tak aby EUP mógł udzielić, na wniosek zgłaszającego, patentu wyznaczającego Unię jako miejsce ochrony. Przystapienie Unii do KPE wymagałoby zmiany tej konwencji ${ }^{24}$ oraz ratyfikowania zmiany przez państwa strony. W rezultacie KPE stałaby się częścią unijnego acquis, w związku z czym podlegałaby wykładni dokonywanej przez TS. Takie podejście, zakładające przystąpienie Unii do KPE, było przyjmowane w projekcie rozporządzenia mającego utworzyć patent unijny, zawartym we wniosku Komisji Europejskiej z 1 sierpnia 2000 r. i kolejnych wariantach tego projektu aż do ostatniej wersji z 27 listopada 2009 r. ${ }^{25}$ Ostatecznie nie zostało ono przyjęte.

Jednolity skutek ma powstawać - na wniosek uprawnionego z patentu europejskiego złożony w EUP - na terytoriach państw członkowskich Unii Europejskiej uczestniczących we wzmocnionej współpracy, a ściślej: w tych spośród nich, które w dniu wpisania jednolitego skutku do rejestru jednolitej ochrony patentowej będą związane porozumieniem JSP (zob. przytoczony wyżej art. 18 ust. 2 akapit drugi rozporządzenia nr 1257/12). Patenty te nie zapewnią jednak jednolitej ochrony w całej Unii, lecz tylko we wspomnianych wyżej państwach, a co więcej - nie będą one jednolite, lecz będa podlegały prawom ustalonym na podstawie art. 5 ust. 3 rozporządzenia nr 1257/12 (zob. niżej).

\footnotetext{
${ }^{23}$ Art. 6 rozporządzenia nr 1260/12 przewiduje, że w okresie przejściowym mającym trwać do dnia udostępnienia ,wysokiej jakości tłumaczeń maszynowych”, właściciel patentu europejskiego będzie zobowiązany dołączyć do wniosku o rejestrację jednolitego skutku: a) tłumaczenie opisu patentowego na język angielski, jeśli językiem postępowania przed EUP był francuski bądź niemiecki albo b) tłumaczenie opisu patentowego na dowolny inny język urzędowy Unii Europejskiej, jeśli językiem postępowania przed EUP był język angielski. Tłumaczenia te maja być wprawdzie publikowane przez EUP, jednak nie będa miały mocy prawnej.

${ }^{24}$ Zob. projekt zmian KPE, zawarty w dokumencie Rady nr 13707/09 z 29 września 2009 r., przygotowany w związku z ówcześnie rozważanym przystąpieniem Unii Europejskiej do tej konwencji.

${ }^{25}$ Zob. dokument Rady nr 16113/09 ADD 1.
} 
Warunkiem powstania jednolitego skutku ma być wpisanie tego skutku do rejestru jednolitej ochrony patentowej ${ }^{26}$. Wpis ma być dokonywany na wniosek uprawnionego z patentu europejskiego, który będzie mógł złożyć taki wniosek w języku postępowania przed EUP ${ }^{27}$ - nie później niż miesiąc po opublikowaniu w „Europejskim Biuletynie Patentowym” informacji o udzieleniu patentu europejskiego. Wniosek o zarejestrowanie jednolitego skutku będzie mógł dotyczyć patentów europejskich udzielonych począwszy od dnia rozpoczęcia stosowania rozporządzeń $\mathrm{nr}$ 1257/12 i nr 1260/12. Miało to być możliwe od 1 kwietnia 2014 r., jednakże stało się nierealne choćby ze względu na czas przeprowadzenia krajowych procedur ratyfikacyjnych dotyczących porozumienia JSP w przynajmniej 13 państwach członkowskich.

Jak stanowi art. 3 ust. 1 rozporządzenia $\mathrm{nr}$ 1257/12: ,patent europejski udzielony $\mathrm{z}$ tym samym zestawem zastrzeżeń $\mathrm{w}$ odniesieniu do wszystkich uczestniczących państw członkowskich ma jednolity skutek w uczestniczących państwach członkowskich pod warunkiem zarejestrowania takiego jednolitego skutku w rejestrze jednolitej ochrony patentowej”. Rejestr ten ma być częścią europejskiego rejestru patentowego prowadzonego przez EUP (zob. art. 127 $\mathrm{KPE}$ ) i ma w nim być rejestrowany nie tylko jednolity skutek, lecz także ograniczenia, licencje, przeniesienie, unieważnienie i wygaśnięcie patentu europejskiego o jednolitym skutku.

Według art. 3 ust. 2 rozporządzenia nr 1257/12: ,patent europejski o jednolitym skutku ma jednolity charakter. Zapewnia on jednolitą ochronę oraz ma taki sam skutek we wszystkich uczestniczących państwach członkowskich". W dalszej części przepis stanowi, że patent ten może zostać ograniczony, przeniesiony, unieważniony lub może wygasnąć tylko w odniesieniu do wszystkich uczestniczących państw członkowskich. Przewiduje się jednak, że może on być przedmiotem licencji w odniesieniu do całości lub części terytoriów uczestniczących państw członkowskich. Jednolity skutek będą miały tylko licencje (licences of right), o których mowa w art. 8 rozporządzenia nr 1257/12 (podobne do licencji otwartej uregulowanej w art. 80 p.w.p.). Rozporządzenie nie reguluje licencji przymusowych ${ }^{28}$.

W rozdziale II rozporządzenia, opatrzonym nagłówkiem „Skutki patentu europejskiego o jednolitym skutku", miała być uregulowana treść praw wyłącznych, obejmująca zarówno prawo zakazania bezpośredniego korzystania $\mathrm{z}$ wynalazku (art. 6), jak i prawo zakazania pośredniego korzystania z wynalazku (art. 7), a także ograniczenia tego patentu (art. 8). Ostateczna wersja rozporządzenia $\mathrm{nr}$ 1257/12 nie zawiera jednak tych przepisów ${ }^{29}$, a zamiast

${ }^{26}$ Patent europejski o jednolitym skutku ma wywierać taki skutek w uczestniczących państwach członkowskich od dnia opublikowania przez EUP w „Europejskim Biuletynie Patentowym” wzmianki o udzieleniu patentu europejskiego (art. 4 ust. 1). Zob. też jednak przytoczony wyżej art. 18 ust. 2 akapit drugi rozporządzenia nr 1257/12.

${ }^{27}$ Językiem postępowania jest jeden z trzech języków urzędowych EUP (angielski, francuski bądź niemiecki). Chodzi o ten spośród wymienionych języków, w którym zostało dokonane europejskie zgłoszenie patentowe lub na który zgłoszenie to zostało przetłumaczone (zob. art. $14 \mathrm{KPE}$ ).

${ }^{28}$ Licencje przymusowe mają podlegać prawodawstwu uczestniczących państw członkowskich w odniesieniu do ich odnośnych terytoriów (zob. motyw 10 preambuły).

${ }^{29}$ Sugestia skreślenia art. 6-8 projektu rozporządzenia została wyrażona 29 czerwca 2012 r. przez Radę Europejską (zob. dokument EUCO 76/12). 
nich - w wyniku tzw. kompromisu cypryjskiego - wprowadzony został art. 5 (zob. niżej).

Zamieszczenie $\mathrm{w}$ unijnym rozporządzeniu regulacji dotyczących treści uprawnień wynikających z jednolitego patentu (i ich ograniczeń) oznaczałoby, że regulacje te byłyby częścią prawa Unii Europejskiej, w związku z czym ich wykładnia byłaby objęta kompetencją TS. Porozumienie JSP przewiduje $\mathrm{w}$ art. 21, że sąd ten będzie występował do TS z wnioskami o wydanie orzeczeń $\mathrm{w}$ trybie prejudycjalnym stosownie do art. 267 TfUE. Wystapienie przez JSP z pytaniami prejudycjalnymi miałoby wpływ na czas trwania postępowań w sprawach o naruszenie patentów oraz koszt tych postępowań. Zwracali na to uwage znawcy prawa i praktyki patentowej i - dostrzegając ponadto brak doświadczenia sędziów TS $\mathrm{w}$ kwestiach związanych $\mathrm{z}$ treścią patentu, wymagających specjalistycznej wiedzy technicznej - domagali się skreślenia regulacji zawartych $\mathrm{w}$ art. 6-8 projektu, tak aby wyeliminować udział TS w rozstrzyganiu tych kwestii ${ }^{30}$. Mimo że wspomniane obiekcje należało uznać za zasadne, to jednak trudno było podzielić zgłaszane w związku z tym propozycje, aby regulacje te zamieścić $\mathrm{w}$ umowie międzynarodowej tworzącej JSP, gdyż okazałoby się wówczas, że unijne rozporządzenie nie określa jednolitego skutku, a zatem nie posiada - w swej zasadniczej części - treści normatywnej.

$\mathrm{Za}$ rozwiązanie tego problemu uznano wspomniany już kompromis cypryjski ${ }^{31}$, polegający na tym, że - zamiast skreślonych przepisów art. 6-8 projektu - w rozporządzeniu $\mathrm{nr}$ 1257/12 zamieszczono art. 5. Jest on opatrzony nagłówkiem „Jednolita ochrona” i w ust. 1 stanowi: „Patent europejski o jednolitym skutku przyznaje jego właścicielowi prawo do uniemożliwienia jakiejkolwiek osobie trzeciej popełniania czynów, przed którymi ten patent zapewnia ochronę, na terytoriach uczestniczących państw członkowskich, w których patent ten ma jednolity skutek, z zastrzeżeniem obowiązujących ograniczeń”. Według art. 5 ust. 2: ,Zakres tego prawa i jego ograniczenia sa jednolite we wszystkich uczestniczących państwach członkowskich, w których patent ma jednolity skutek”. Wreszcie, jak stanowi art. 5 ust. 3: „Czynami, przed którymi patent zapewnia ochronę, o których mowa w ust. 1, oraz obowiązującymi ograniczeniami są czyny i ograniczenia określone przez prawo stosowane wobec patentów europejskich o jednolitym skutku w tym uczestniczącym państwie członkowskim, którego prawo krajowe ma zastosowanie do danego patentu europejskiego o jednolitym skutku jako przedmiotu własności zgodnie z art. 7”. W kontekście zwrotu ,,czyny, przed którymi patent zapewnia ochronę" należy wyjaśnić, że odnosi się on do czynów objętych wyłącznością wynikająca $\mathrm{z}$ patentu, będącego prawem bezwzględnym, skutecznym erga omnes. Ze względu na tę wyłączność uprawniony $\mathrm{z}$ patentu (określany w rozporządzeniu nr 1257/12 mianem „właściciel”) może zakazać którego-

${ }^{30}$ Zob. np. European Patent Lawyers Association, The Unified Patent Court. EPLAW Resolution on the Draft Agreement 13751/11 of September 2, 2011; R. Kraßer, Effects of an Inclusion of Regulations Concerning the Content and Limits of the Patent Holder's Rights to Prohibit in an EU Regulation for the Creation of Unitary European Patent Protection; R. Jacob, Opinion, $2^{\text {nd }}$ November 2011 (wymienione materiały są dostępne na: http://www.eplawpatentblog.com).

${ }^{31}$ Propozycję tę przedstawiła ówczesna prezydencja cypryjska, a 19 listopada 2012 r. została ona zaakceptowana przez Coreper oraz komisję prawną Parlamentu Europejskiego. 
kolwiek z tych czynów wszystkim osobom niemającym jego zgody (licencji), chyba że dany czyn jest objęty jednym z ograniczeń patentu ${ }^{32}$.

$\mathrm{W}$ celu wyjaśnienia sensu prawnego regulacji zawartej $\mathrm{w}$ art. 5 ust. 3 rozporządzenia $\mathrm{nr}$ 1257/12 niezbędne jest przedstawienie reguł określających prawo krajowe mające zastosowanie do patentu europejskiego o jednolitym skutku ,jako przedmiotu własności” ${ }^{33}$.

Reguły te sa zawarte $\mathrm{w}$ art. 7 rozporzadzenia $\mathrm{nr} 1257 / 12$, opatrzonym nagłówkiem ,Traktowanie patentu europejskiego o jednolitym skutku jako patentu krajowego”. Według art. 7 ust. 1: ,,patent europejski o jednolitym skutku jako przedmiot własności traktuje się w całości i we wszystkich uczestniczących państwach członkowskich jako patent krajowy uczestniczącego państwa członkowskiego, w którym dany patent ma jednolity skutek i w którym, zgodnie z Europejskim Rejestrem Patentowym: a) znajdowało się miejsce zamieszkania lub siedziba lub główne miejsce prowadzenia działalności zgłaszającego $\mathrm{w}$ dniu dokonania europejskiego zgłoszenia patentowego; lub b) w przypadku gdy lit. a) nie ma zastosowania, znajdowało się miejsce prowadzenia działalności zgłaszającego $\mathrm{w}$ dniu dokonania europejskiego zgłoszenia patentowego" ${ }^{34}$. Natomiast ,,w przypadku gdy żaden ze zgłaszających nie miał miejsca zamieszkania, siedziby, głównego miejsca prowadzenia działalności ani miejsca prowadzenia działalności w uczestniczącym państwie członkowskim, w którym dany patent ma jednolity skutek do celów ust. 1 lub 2, patent europejski o jednolitym skutku jako przedmiot własności traktuje się w całości i we wszystkich uczestniczących państwach członkowskich jako patent krajowy państwa, w którym zgodnie z art. 6 ust. 1 konwencji o patencie europejskim znajduje się siedziba Europejskiej Organizacji Patentowej" (art. 7 ust. 3 rozporządzenia $\mathrm{nr}$ 1257/12). Siedziba wspomnianej organizacji znajduje się w RFN (Monachium), z czego wynika, że w omawianym przypadku patent europejski o jednolitym skutku będzie traktowany - jako przedmiot własności jako patent krajowy RFN.

Komentując to rozwiązanie, warto zaznaczyć, że jest ono analogiczne do tego, które obowiązuje np. w stosunku do wspólnotowego znaku towarowego ${ }^{35}$, przy czym w tym przypadku chodzi o hiszpański krajowy znak towarowy, gdyż w tym państwie mieści się siedziba unijnego urzędu rejestrującego wspólnotowe znaki towarowe (OHIM). Traktowanie unijnych praw własności intelektualnej

\footnotetext{
${ }^{32}$ Chodzi o uregulowane przepisami prawa sytuacje, w których dozwolone jest korzystanie z opatentowanego wynalazku bez zgody (licencji) uprawnionego z patentu. W art. 5 rozporządzenia nr 1257/12 są one określane jako „obowiązujące ograniczenia”, a w porozumieniu JSP (art. 27) jako „ograniczenia skutków patentu” (zob. niżej).

${ }^{33}$ Przy ustalaniu znaczenia zwrotu ,jako przedmiot własności” (as an object of property) można się odwołać do regulacji dotyczącej wspólnotowego znaku towarowego zawartej w art. 16-24 rozporządzenia nr 207/2009 (Dz. Urz. UE L 78 z 24 marca 2009 r.). Zob. też art. 27-34 rozporządzenia nr 6/2002 w sprawie wzorów wspólnotowych (Dz. Urz. WE L 3 z 5 stycznia 2002 r., s. 1).

${ }^{34}$ Jak stanowi art. 7 ust. 2, ,w przypadku gdy do Europejskiego Rejestru Patentowego wpisano jako współzgłaszających co najmniej dwie osoby, ust. 1 lit. a) stosuje się do pierwszego wymienionego współzgłaszającego. Jeśli to nie jest możliwe, ust. 1 lit. a) stosuje się do następnego wymienionego współzgłaszającego, w kolejności wpisu. Jeśli do żadnego ze współzgłaszających nie stosuje się ust. 1 lit. a), odpowiednio stosuje się ust. 1 lit. b)".

${ }^{35}$ Zob. wyżej przypis 33.
} 
przysługujacych podmiotom spoza Unii Europejskiej jako „,przedmiotu własności" - w zakresie nieuregulowanym w legislacji unijnej - jako praw krajowych określonego państwa członkowskiego nie jest więc czymś niezwykłym ani nie powinno budzić zdziwienia także w stosunku do patentów europejskich o jednolitym skutku, w odniesieniu do których chodzi jednak nie tylko o państwa spoza Unii, lecz także o państwa członkowskie nieuczestniczące we wzmocnionej współpracy, a nadto o te uczestniczące państwa członkowskie, które nie zwiążą się porozumieniem JSP. W razie więc niezwiązania się przez Polskę porozumieniem JSP przysługujący podmiotowi polskiemu patent europejski o jednolitym skutku będzie traktowany $\mathrm{w}$ uczestniczących państwach członkowskich, w których będzie miał jednolity skutek - jako przedmiot własności - jako patent krajowy RFN. Jest to sytuacja porównywalna w pewnej mierze $\mathrm{z}$ istniejąca obecnie $\mathrm{w}$ stosunku do patentów krajowych i patentów europejskich. Na przykład, jeśli podmiot polski uzyska krajowy patent niemiecki bądź dokona w RFN walidacji patentu europejskiego, to każdy $\mathrm{z}$ tych patentów podlega prawu RFN (lex loci protectionis). Analogicznie uzyskany przez podmiot polski patent francuski bądź patent europejski walidowany we Francji podlega prawu francuskiemu. Wynika to z zasady terytorializmu praw własności intelektualnej, wyrażonej także w polskim prawie prywatnym międzynarodowym ${ }^{36}$.

Regulacja zawarta w art. 5 ust. 3 rozporządzenia nr 1257/12 oznacza, że treść jednolitego skutku (treść praw wyłącznych i ich ograniczenia) będzie określona przez ,prawo stosowane wobec patentów europejskich o jednolitym skutku" w tym uczestniczącym państwie członkowskim, którego prawo krajowe ma zastosowanie do danego patentu europejskiego o jednolitym skutku jako przedmiotu własności zgodnie z przytoczonym wyżej art. 7 rozporządzenia. Jeśli więc $\mathrm{np}$. zgłaszający miał $\mathrm{w}$ dacie dokonania europejskiego zgłoszenia patentowego główne miejsce prowadzenia działalności w Holandii, to treść jednolitego skutku będzie podlegała prawu stosowanemu wobec patentów europejskich o jednolitym skutku w Holandii. Natomiast $\mathrm{z}$ art. 7 ust. 3 rozporządzenia nr 1257/12 wynika, że treść jednolitego skutku patentów europejskich udzielonych na rzecz podmiotów, które w dacie zgłoszenia nie miały miejsca zamieszkania, siedziby, głównego miejsca prowadzenia działalności ani miejsca prowadzenia działalności w uczestniczącym państwie członkowskim, w którym dany patent ma jednolity skutek, będzie podlegała prawu stosowanemu wobec patentów europejskich o jednolitym skutku w RFN.

Efekt zastosowania art. 5 ust. $3 \mathrm{w}$ zwiazku $\mathrm{z}$ art. 7 rozporządzenia nr 1257/12 jest zaskakujący. Okazuje się bowiem, że w państwach, w których będą obowiązywały patenty europejskie o jednolitym skutku, powstanie „mozaika” jednolitych skutków, których treść będzie podlegała prawu stosowanemu wobec patentów europejskich o jednolitym skutku w tym uczestniczącym państwie członkowskim, w którym w dniu dokonania europejskiego zgłoszenia patentowego zgłaszający miał miejsce zamieszkania, siedzibę, główne miejsce prowadzenia działalności albo miejsce prowadzenia działalności. Tak więc np. we wszystkich państwach, w których będą obowiązywały patenty

${ }^{36}$ Zob. art. 46 ustawy z 4 lutego 2011 r. - Prawo prywatne międzynarodowe (Dz. U. Nr 80, poz. 432). 
europejskie o jednolitym skutku, treść tego skutku zarejestrowanego na rzecz zgłaszającego z Holandii będzie podlegała prawu stosowanemu wobec patentów europejskich o jednolitym skutku w Holandii (a na rzecz zgłaszającego ze Szwecji-prawu stosowanemu wobec patentów europejskich o jednolitym skutku w Szwecji). Natomiast treść jednolitego skutku zarejestrowanego na rzecz zgłaszającego ze Stanów Zjednoczonych będzie podlegała prawu stosowanemu wobec patentów europejskich o jednolitym skutku w RFN. To samo będzie dotyczyć patentów o jednolitym skutku zarejestrowanych na rzecz zgłaszających z Polski (i innych państw uczestniczących we wzmocnionej współpracy, które nie zwiążą się porozumieniem JSP), a także z państw Unii Europejskiej nieuczestniczących we wzmocnionej współpracy (Hiszpania, Włochy), czy wreszcie z państw nienależących do Unii Europejskiej. Wprawdzie w każdym z państw, w których będą obowiązywały patenty europejskie o jednolitym skutku, treść jednolitego skutku danego patentu będzie podlegała temu samemu prawu (w tym sensie zakres tego prawa i jego ograniczenia sa ,jednolite” w rozumieniu art. 5 ust. 2 rozporządzenia $\mathrm{nr} 1257 / 12$ ), jednakże poszczególne patenty europejskie będą miały jednolity skutek o treści określonej przez rozmaite prawa, w zależności od miejsca zamieszkania, siedziby, głównego miejsca prowadzenia działalności albo miejsca prowadzenia działalności zgłaszającego.

Poza zastrzeżeniami konstrukcyjnymi omawiana regulacja budzi też wątpliwości co do zgodności z art. 118 TfUE, będącym podstawą prawną rozporządzenia $\mathrm{nr} 1257 / 12$. Wbrew powołanemu przepisowi, w którym jest mowa o tworzeniu ,,europejskich praw własności intelektualnej w celu zapewnienia jednolitej ochrony praw własności intelektualnej w Unii”, rozporządzenie nr 1257/12 nie określa treści jednolitego skutku patentu europejskiego mającego zapewniać ową jednolitą ochronę, lecz odsyła w tej mierze do prawa, o którym mowa w art. 5 ust. 3 , tzn. do ,prawa stosowanego wobec patentów europejskich o jednolitym skutku" we wskazanym w tym przepisie uczestniczącym państwie członkowskim.

Powyższa analiza nie wyczerpuje problemów związanych z określeniem treści jednolitego skutku. Należy bowiem ustalić, do jakiego zbioru przepisów prawnych odnosi się użyty w art. 5 ust. 3 rozporządzenia nr 1257/12 zwrot „,prawo stosowane wobec patentów europejskich o jednolitym skutku”. Zaznaczyć należy, że w przytoczonym sformułowaniu mowa jest o ,prawie stosowanym" wobec omawianych patentów we wskazanym państwie członkowskim, nie zaś - jak w końcowej części tego postanowienia - o ,prawie krajowym" tego państwa. Przystępując do próby odkodowania sensu prawnego tej regulacji, należy mieć na uwadze, że wprowadzeniu art. 5 rozporządzenia nr 1257/12 towarzyszyło założenie, że uczestniczące państwa członkowskie, w których obowiązywać będzie jednolity skutek, będą związane porozumieniem JSP, a zatem postanowienia tej umowy międzynarodowej staną się częścią prawa tych państw. Dotyczy to w szczególności art. 25-28 porozumienia JSP, obejmujących prawo materialne, w tym regulacje określające treść praw wyłącznych i ich ograniczenia. Artykuł 25 porozumienia JSP reguluje prawo zakazania bezpośredniego korzystania z wynalazku, art. 26 - prawo zakazania pośredniego korzystania z wynalazku, art. 27 - ograniczenia skutków patentu, 
art. 28 - prawo oparte na uprzednim stosowaniu wynalazku. W projektach porozumienia JSP, począwszy od pierwotnej wersji z 14 czerwca $2011 \mathrm{r}^{37}$ aż do wersji z 12 października $2012 \mathrm{r}^{38}$, wymienione przepisy (oznaczone ówcześnie jako art. 14f-14i) dotyczyły tylko „klasycznych” patentów europejskich, gdyż odnośnie do patentów europejskich o jednolitym skutku omawiane kwestie (obecnie objęte art. 25-27 porozumienia JSP) miały być regulowane unijnym rozporządzeniem. W ostatecznej wersji porozumienia JSP regulacje te rozciągnięto jednak również na patenty europejskie o jednolitym skutku ${ }^{39}$, co wiązało się z decyzją o skreśleniu art. 6-8 projektu rozporządzenia. Skoro więc postanowienia art. 25-28 porozumienia JSP dotyczą również patentów europejskich o jednolitym skutku, to wynika stąd, że przepis art. 5 ust. 3 rozporządzenia $\mathrm{nr}$ 1257/12 odsyła pośrednio do wspomnianych postanowień porozumienia JSP. Będą one bowiem częścią ,prawa stosowanego wobec patentów europejskich o jednolitym skutku" w uczestniczących państwach członkowskich związanych porozumieniem JSP, a zatem na ich podstawie określane będa ,,czyny” i ,obowiązujące ograniczenia”, o których mowa w art. 5 ust. 1 i 3 rozporządzenia nr 1257/12, tzn. treść jednolitego skutku patentu europejskiego.

Okazuje się więc, że „prawem stosowanym wobec patentów europejskich o jednolitym skutku", określającym treść tego skutku (treść praw wyłącznych i ich ograniczenia) mają być postanowienia porozumienia JSP. Uwzględniając okoliczność, że będą one obowiązywać we wszystkich państwach związanych ta umową międzynarodowa, tzn. w tych państwach, w których patent europejski będzie miał jednolity skutek, można - jak się wydaje - założyć, że treść praw wyłącznych i ich ograniczenia będą takie same we wszystkich tych państwach, gdyż będą określone postanowieniami porozumienia JSP. Jakkolwiek więc $\mathrm{w}$ art. 5 ust. 3 in fine rozporządzenia $\mathrm{nr} 1257 / 12$ jest mowa o prawie stosowanym wobec patentów europejskich o jednolitym skutku „w tym uczestniczącym państwie członkowskim, którego prawo krajowe ma zastosowanie do danego patentu europejskiego o jednolitym skutku jako przedmiotu własności zgodnie z art. 7", to jednak należy przyjąć, że w każdym uczestniczącym państwie członkowskim treść jednolitego skutku będzie określona przez te same przepisy, którymi będą art. 25-27 porozumienia JSP. Uwzględniając iunctim pomiędzy obu rozporządzeniami i porozumieniem JSP, a także biorąc pod uwagę fakt, że wymienione akty prawne będą stosowane przez JSP, a nie przez sądy krajowe, można także założyć, że omawiana grupa postanowień JSP będzie stosowana w sposób jednolity, chociaż nie można wykluczyć rozbieżności interpretacyjnych $\mathrm{w}$ orzeczeniach poszczególnych oddziałów lokalnych lub regionalnych JSP. Natomiast ,niejednolitość” jednolitego patentu dotyczyć będzie tych jego aspektów, które z mocy art. 7 rozporządzenia nr 1257/12 będa

${ }^{37}$ Zob. dokument Rady nr 11533/11.

${ }^{38}$ Zob. dokument Rady nr 14750/12.

39 Osiagnięto to w ten sposób, że w wyrażeniu ,,patent europejski” występującym w projektach tych przepisów skreślono wyraz „,europejski”. Pozostały po tym zabiegu wyraz ,,patent” oznacza - według definicji zawartej w art. 2 lit. g porozumienia JSP - oba rodzaje patentów: patent europejski oraz patent europejski o jednolitym skutku. 
podlegać prawom krajowym (chodzi o kwestie związane z traktowaniem tego patentu ,jako przedmiotu własności").

Jak wspomniano, porozumienie JSP ma być zawarte tylko pomiędzy państwami członkowskimi Unii Europejskiej, bez udziału samej Unii. Nie będzie więc częścią unijnego acquis, $\mathrm{w}$ związku $\mathrm{z}$ czym wykładnia tej umowy międzynarodowej nie będzie objęta kompetencja TS (z pewnymi wyjątkami, dotyczącymi np. postanowień odwołujących się do przepisów unijnych dyrektyw $)^{40}$. Nie sposób przewidzieć, czy odesłanie zawarte w art. 5 ust. 3 rozporządzenia $\mathrm{nr}$ 1257/12 zostanie uznane przez TS za wystarczająca podstawę do dokonywania wykładni art. 25-27 porozumienia JSP, określających treść jednolitego skutku. Ponownie wskazać należy, że właśnie wyeliminowanie udziału TS było głównym motywem skreślenia art. 6-8 projektu rozporządzenia.

\section{TREŚĆ JEDNOLITEGO SKUTKU PATENTU EUROPEJSKIEGO (PRAWA WYŁĄCZNE I ICH OGRANICZENIA)}

Treść jednolitego skutku patentu europejskiego (a także treść praw wyłącznych wynikających $\mathrm{z}$,klasycznego” patentu europejskiego), określona w art. 25-27 porozumienia JSP, obejmuje prawo zakazania bezpośredniego korzystania z wynalazku (art. 25), prawo zakazania pośredniego korzystania z wynalazku (art. 26), a także ograniczenia skutków obu patentów (art. 27).

Prawo zakazania bezpośredniego korzystania $\mathrm{z}$ wynalazku jest ujęte podobnie jak w art. 28 ust. 1 porozumienia TRIPS $^{41}$ (oraz w art. 66 ust. 1 p.w.p.). Artykuł 25 porozumienia JSP stanowi, że patent uprawnia właściciela do zakazania każdej osobie trzeciej, niemającej jego zgody: a) wytwarzania, oferowania, wprowadzania do obrotu lub używania produktu będącego przedmiotem patentu, a także importowania lub przechowywania tego produktu do wspomnianych celów; b) stosowania sposobu wytwarzania będącego przedmiotem patentu lub, jeśli osoba trzecia wie lub powinna była wiedzieć, że zastosowanie tego sposobu wytwarzania bez zgody właściciela patentu jest zakazane, oferowania tego sposobu wytwarzania do zastosowania na terytorium umawiających się państw członkowskich, w których patent ten ma skutek; c) oferowania, wprowadzania do obrotu, używania, importowania lub przechowywania do wspomnianych celów produktu uzyskanego bezpośrednio w drodze zastosowania sposobu wytwarzania będącego przedmiotem patentu.

Artykuł 26 porozumienia JSP, przyznający ,,prawo zakazania pośredniego korzystania z wynalazku", stanowi w ust. 1, że patent uprawnia właściciela do zakazania każdej osobie trzeciej, niemającej jego zgody, zaopatrywania lub

\footnotetext{
${ }^{40}$ Zob. np. art. 27 lit. 1 porozumienia JSP, odwołujący się do art. 10 dyrektywy 98/44/WE.

${ }^{41}$ Porozumienie w sprawie handlowych aspektów praw własności intelektualnej (Dz. U. 1996, Nr 32, poz. 143 - załącznik). Na temat pozycji TRIPS w porządku prawnym Unii Europejskiej zob. wyrok TS z 18 lipca 2013 r., C-414/11 Daiichi Sankyo Co. Ltd, Sanofi-Aventis Deutschland GmbH v. DEMO Anonymos Viomichaniki kai Emporiki Etairia Farmakon (Dz. Urz. C 260 z 7 września 2013 r., s. 6).
} 
oferowania zaopatrywania na terytorium umawiających się państw członkowskich, w których dany patent ma skutek, jakiejkolwiek osoby innej niż strona uprawniona do korzystania z wynalazku chronionego patentem w środki odnoszące się do zasadniczego elementu tego wynalazku, umożliwiające jego praktyczne zastosowanie $\mathrm{w}$ tych państwach członkowskich, jeśli osoba trzecia wie lub powinna była wiedzieć, że takie środki są odpowiednie i przeznaczone do praktycznego zastosowania tego wynalazku. Stosownie do art. 26 ust. 2 porozumienia JSP, ust. 1 nie ma zastosowania, jeśli takie środki sa standardowymi produktami komercyjnymi, z wyjątkiem przypadków nakłaniania przez osobę trzecią osoby zaopatrywanej do podejmowania działań zabronionych przez art. 25 . Według art. 26 ust. 3 porozumienia JSP osób podejmujących działania, o których mowa w art. 27 lit. a-e, nie uważa się za strony uprawnione do korzystania $\mathrm{z}$ wynalazku w rozumieniu ust. 1.

Powyższe ujęcie prawa zakazania pośredniego korzystania z wynalazku jest wzorowane na regulacji zawartej w konwencji luksemburskiej z 1975 r. (która miała utworzyć patent dla ówczesnej EWG, lecz nie weszła w życie ${ }^{42}$, a występuje np. w ustawach patentowych $\mathrm{RFN}^{43}$ i Wielkiej Brytanii ${ }^{44}$, natomiast nie zostało wyrażone ani w porozumieniu TRIPS, ani w prawie polskim. Regulacja zawarta w art. 26 porozumienia JSP stanowić będzie podstawę zarzutów dotyczących pośredniego naruszenia patentu, co oznaczać będzie istotne wzmocnienie ochrony wynikajacej $\mathrm{z}$ obu rodzajów patentów: patentu europejskiego o jednolitym skutku i ,klasycznego” patentu europejskiego.

Jednolite mają być również ograniczenia skutków patentu, dotyczące zarówno patentu europejskiego o jednolitym skutku, jak i „klasycznego” patentu europejskiego. Określa je art. 27 porozumienia JSP, stanowiący, że prawa przyznane patentem nie rozciągaja się m.in. na: a) działania dokonane w celach prywatnych i niehandlowych; b) działania podejmowane w celach doświadczalnych dotyczace przedmiotu wynalazku chronionego patentem; c) wykorzystywanie materiału biologicznego do celów hodowli lub odkrywania i tworzenia innych odmian roślin; d) działania dozwolone zgodnie $\mathrm{z}$ art. 13 ust. 6 dyrektywy 2001/82/WE ${ }^{45}$ lub z art. 10 ust. 6 dyrektywy 2001/83/WE ${ }^{46}$ w odniesieniu do każdego patentu chroniacego produkt w rozumieniu którejkolwiek z tych dyrektyw; e) doraźne wykonanie leku w aptece w indywidualnych przypadkach, zgodnie $\mathrm{z}$ receptą lekarską, ani na działania dotyczące tak przygotowanego leku ${ }^{47}$.

Artykuł 28 porozumienia JSP reguluje ,,prawo oparte na uprzednim stosowaniu wynalazku” i stanowi, że „każdej osobie, która - gdyby dla danego

${ }^{42}$ Convention for the European Patent for the Common Market (Dz. Urz. WE L 17 z 26 stycznia 1976 r.). Zob. też Agreement Relating to Community Patents (Dz. Urz. WE L 401 z 30 grudnia 1989 r.). Spośród ówczesnych 12 państw członkowskich ratyfikacji dokonało tylko 7 państw.

${ }^{43}$ Zob. § 10 niemieckiej ustawy patentowej (Patentgesetz). Zob. też np. wyrok Federalnego Sądu Najwyższego (BGH) z 7 maja 2013 r., X ZR 69/11 Fräsverfahren (www.bundesgerichtshof.de).

${ }^{44}$ Zob. art. 60 (2) brytyjskiej ustawy patentowej (Patents Act). Zob. też np. wyrok Sądu Apelacyjnego dla Anglii i Walii z 28 listopada 2002 r., Menashe Business Mercantile Limited v. William Hill Organization Limited, [2002] EWCA Civ 1702 (www.bailii.org/).

${ }^{45}$ Dz. Urz. WE L 311 z 28 listopada 2001 r., ze zm.

${ }^{46}$ Dz. Urz. WE L 311 z 28 listopada 2001 r., ze zm.

${ }^{47}$ Ponadto zob. art. 27 lit. f)-l) porozumienia JSP. 
wynalazku został udzielony patent krajowy - miałaby na terytorium umawiającego się państwa członkowskiego prawo oparte na uprzednim stosowaniu tego wynalazku lub prawo osobistego posiadania tego wynalazku, przysługują na terytorium tego umawiającego się państwa członkowskiego te same prawa w odniesieniu do patentu dla tego samego wynalazku".

Wreszcie, art. 29 porozumienia JSP reguluje wyczerpanie praw przyznanych na mocy patentu europejskiego i stanowi, że prawa te „nie rozciagają się na działania dotyczace produktu chronionego tym patentem po wprowadzeniu tego produktu do obrotu w Unii Europejskiej przez właściciela patentu lub za jego zgoda, chyba że istnieją uzasadnione podstawy do tego, by właściciel patentu sprzeciwiał się dalszemu udostępnianiu produktu na zasadach handlowych”. Przepis ten dotyczy tylko ,klasycznego” patentu europejskiego, natomiast wyczerpanie praw wynikających $\mathrm{z}$ patentu europejskiego o jednolitym skutku jest uregulowane w art. 6 rozporządzenia $\mathrm{nr}$ 1257/12.

Przytoczone przepisy określać będą treść praw wyłącznych przysługujących zarówno właścicielom patentów europejskich o jednolitym skutku, jak i właścicielom „klasycznych” patentów europejskich. Jakiekolwiek działanie osób trzecich wchodzące $\mathrm{w}$ zakres uprawnień określonych w art. 25 i 26 porozumienia JSP i nieobjęte ramami ograniczeń przewidzianych w art. 27 (oraz regulacjami zawartymi w art. 28 i 29 ) stanowić będzie naruszenie patentu, a jego właściciel będzie mógł dochodzić roszczeń i innych środków prawnych określonych w porozumieniu JSP (zob. zwłaszcza art. 56-72).

Jak wspomniano, sprawy o naruszenie patentów obu rodzajów (i SPC) maja należeć do wyłącznej jurysdykcji JSP, z tym jednak, że w odniesieniu do „klasycznych” patentów europejskich przewidziano okres przejściowy (art. 83 porozumienia JSP), w ciągu którego możliwe będzie - na wniosek uprawnionego - wyłączenie kompetencji tego sądu (opt-out).

Treść „klasycznych” patentów europejskich w uczestniczących państwach członkowskich, które nie ratyfikuja porozumienia JSP (a także w pozostałych państwach stronach KPE), będzie podlegać ustawodawstwom krajowym tych państw, a sprawy o naruszenie takich patentów nadal będą w tych państwach należeć do jurysdykcji sądów krajowych, z tym że w odniesieniu do państw stron KPE będących członkami Unii Europejskiej jurysdykcję tę będzie określać rozporządzenie nr 44/2001 (a od 10 stycznia 2015 r. rozporządzenie nr 1215/2012). Powyższe zróżnicowanie sytuacji patentowej spowoduje trudne do przezwyciężenia komplikacje przy określaniu treści praw wyłącznych zarówno w państwach Unii, jak i w państwach stronach KPE nienależących do Unii.

\section{UWAGI KOŃCOWE}

Jak wynika z powyższej analizy, konstrukcja prawna jednolitego skutku patentu europejskiego jest niezmiernie złożona i skomplikowana. Sam fakt obowiązywania wielu źródeł prawa regulującego rozmaite aspekty jednolitych patentów (prawo Unii Europejskiej, umowy międzynarodowe, w tym porozumienie JSP oraz KPE, a także systemy prawa krajowego) rodzić będzie 
poważne trudności i niepewność co do treści i zakresu ochrony, a w celu usunięcia tej niepewności niezbędne będą skomplikowane zabiegi rozgraniczające sfery zastosowania poszczególnych porządków prawnych. Wbrew założeniom odwołującym się do utworzenia jednolitej ochrony patentowej, nastąpi dalsza fragmentacja tej ochrony. Tak np., o ile obecnie patenty europejskie skuteczne w Polsce podlegaja prawu polskiemu zarówno ,,jako przedmiot własności”, jak i co do treści praw wyłącznych i ich ograniczeń, o tyle wprowadzenie do Polski patentów jednolitych spowoduje, że powstanie „mozaika” praw patentowych podlegających - ,jako przedmiot własności” prawom krajowym państw uczestniczących we wzmocnionej współpracy (art. 7 rozporządzenia $\mathrm{nr}$ 1257/12), a treść praw wyłącznych i ich ograniczenia podlegać będą - z mocy odesłania zawartego w art. 5 ust. 3 rozporządzenia nr 1257/12 - przepisom porozumienia JSP. Z punktu widzenia sytuacji prawnopatentowej obowiązującej w danym państwie dojdzie więc do rozczłonkowania ochrony patentowej, a nie jej ujednolicenia.

$\mathrm{Na}$ krytyczną ocenę zasługuje również system językowy określony w rozporządzeniu nr 1260/12 ${ }^{48}$, niekorzystny dla podmiotów funkcjonujących w państwach, których językiem urzędowym jest język inny niż angielski, francuski czy niemiecki. Poważne zastrzeżenia, w tym dotyczące zgodności z polska Konstytucją, budzi także system rozstrzygania sporów patentowych uregulowany w porozumieniu $\mathrm{JSP}^{49}$.

W pełni aktualny jest apel o niewiązanie się przez Polskę porozumieniem JSP. Jak bowiem wynika z przytoczonego wyżej art. 18 ust. 2 rozporządzenia $\mathrm{nr} 1257 / 12$, w takim razie patenty europejskie nie będą miały w naszym kraju jednolitego skutku, a zatem nie będą one obowiązywać automatycznie, lecz będą musiały być walidowane i tłumaczone na język polski. W związku z tym można np. oczekiwać, że corocznie ,wchodzić” będzie do Polski znacznie mniej patentów udzielanych przez $\operatorname{EUP}^{50}$ i, co równie istotne, będą one - tak jak obecnie - dostępne w tłumaczeniu na język polski, mającym skutki prawne określone $\mathrm{w}$ art. 70 ust. $3 \mathrm{KPE}$. Nie ulegnie też zmianie natura prawna patentów europejskich obowiązujących w naszym kraju, które nadal będą podlegać prawu polskiemu, a spory dotyczące tych patentów będą w Polsce rozpatrywane na dotychczasowych zasadach przez organy krajowe.

dr hab. Aurelia Nowicka

Profesor Uniwersytetu im. Adama Mickiewicza w Poznaniu aunow@amu.edu.pl

48 Jeden z zarzutów pod adresem systemu językowego wynika stąd, że rozporządzenie nr 1260/12 znosi wymóg dostarczania do krajowych urzędów patentowych tłumaczeń opisów patentowych, przewidziany $\mathrm{w}$ art. $65 \mathrm{KPE}$. Do patentów europejskich o jednolitym skutku nie będą więc miały zastosowania przepisy art. 6 i 7 ustawy z 14 marca 2003 r. (zob. wyżej przypis 7).

${ }^{49}$ Zob. S. Sołtysiński, O projekcie jednolitej ochrony patentowej w Unii Europejskiej, w: Problemy polskiego $i$ europejskiego prawa prywatnego. Ksiega pamiatkowa Profesora Mariana Kepińskiego, Warszawa 2012, s. 385 i n.; A. Nowicka, R. Skubisz, Pakiet patentowy (ocena z perspektywy Polski), „Europejski Przegląd Sądowy” 2013, nr 4, s. 12 i n.

${ }^{50} \mathrm{Na}$ temat liczby patentów europejskich udzielanych przez EUP i walidowanych w Polsce zob. A. Nowicka, Jednolita ochrona patentowa $i$ Jednolity Sad Patentowy - zagrożenia $i$ niekorzystne konsekwencje $w$ Polsce, www.rzecznikpatentowy.org.pl, s. 4-5 i 12. 


\section{EUROPEAN PATENT WITH UNITARY EFFECT - THE LEGAL CONSTRUCT AND CONTENT}

\section{Summary}

This paper presents legal regulations aimed to create unitary patent protection envisaged in Regulation (EU) No 12572012 of the European Parliament and of the Council implementing enhanced cooperation in the area of the creation of unitary patent protection, and Council Regulation (EU) No $1260 / 2012$ implementing enhanced cooperation in the area of the creation of unitary patent protection with regard to the applicable translation arrangements. Since both regulations are closely connected with the Agreement on a Unified Patent Court, the latter will also be discussed.

After a brief presentation of the current state of affairs in individual EU Member States regarding patent protection under European patents and national patents regulations, the legal construct of a European patent with unitary effect adopted in Regulation No 1257/2012 is analysed, with subsequent analysis of the content of the rights conferred by to European patents with unitary effect (i.e. the right to prevent the direct use of the invention and the right to prevent the indirect use of the invention). The last part of the analysis covers limitations of the effects of a patent. It is emphasised that the provisions regulating both the content of the patent and its limitations will not only apply to European patents with unitary effect, but will extend to include the 'classical' European patents as well.

A critical opinion of the three legal acts is formulated. It is argued that once Poland ratifies the Agreement on a Unified Patent Court, European patents with unitary effect will come into force in Poland, and this will result in highly undesirable legal and economic consequences, and be particularly disadvantageous for small and medium-sized enterprises. Further, handing over jurisdiction over patent-related matters to the Unified Patent Court will also bring negative consequences and, what is more, there are serious reasons to believe that doing so would be contrary to Poland's Constitution. 
Copyright of Journal of Law, Economics and Sociology is the property of Faculty of Law and Administration of Adam Mickiewicz University in Poznan and its content may not be copied or emailed to multiple sites or posted to a listserv without the copyright holder's express written permission. However, users may print, download, or email articles for individual use.

Właścicielem praw autorskich do „Ruchu Prawniczego, Ekonomicznego i Socjologicznego” jest Wydział Prawa i Administracji Uniwersytetu im. Adama Mickiewicza w Poznaniu. Zawartość czasopisma nie może być kopiowana, przesyłana do innych stron internetowych bądź zamieszczana na blogach bez pisemnej zgody wydawcy. Niemniej artykuły można drukować, kopiować lub przesyłać w formie elektronicznej na własny użytek. 